\title{
Update on recent key publications in lung oncology: picking up speed
}

\author{
Achim Rittmeyer ${ }^{1,4}$, Annett Schiwitza $\mathbb{1}^{2,4}$, Lejla Sahovic ${ }^{2}$, Bastian Eul ${ }^{3}$ and Stefan Andreas $\mathbb{1}^{1,2}$
}

\section{Number 5 in the Series "Thoracic oncology" Edited by Rudolf Huber and Peter Dorfmüller}

${ }^{1}$ Lungenfachklinik Immenhausen, Immenhausen, Germany. ${ }^{2}$ Dept of Pneumology (Research \& Teaching), Universitätsmedizin Göttingen, Deutsches Zentrum Lungenforschung (DZL), Göttingen, Germany. ${ }^{3}$ Dept of Pneumology, Medical Oncology, Hematology, Universitätsklinikum Gießen-Marburg, Giessen, Germany. ${ }^{4}$ Both authors contributed equally.

Corresponding author: Achim Rittmeyer (arittmeyer@lungenfachklinik-immenhausen.de)

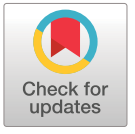

Copyright @ERS 2021

This article is open access and distributed under the terms of the Creative Commons Attribution Non-Commercial Licence 4.0.

This article has supplementary material available from err.ersjournals.com

Received: 16 Sept 2020 Accepted: 30 Nov 2020

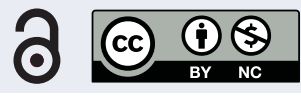

Shareable abstract (@ERSpublications)

In the past two decades, an increasing number of new drugs received EMA approval. The reason for this is an increasingly better understanding of lung cancer, and decreasing mandatory intervals before approval between early and late trials. https://bit.ly/3g1jfpq

Cite this article as: Rittmeyer A, Schiwitza A, Sahovic L, et al. Update on recent key publications in lung oncology: picking up speed. Eur Respir Rev 2021; 30: 200300 [DOI: 10.1183/16000617.0300-2020].

\section{Abstract}

Introduction As incidence rates for lung cancer are still very high and lung cancer remains the most deadly cancer since the turn of the millennium, efforts have been made to find new approaches in cancer research. This systematic review highlights how therapeutic options were extended and how the development of new drugs has picked up speed during the last 20 years.

Methods A systematic search was performed in PubMed, Cochrane Library and the European Union Trial Register and 443 records were identified. Our inclusion criteria constituted completed phase I, II and III studies investigating drugs approved by the European Medicines Agency (EMA). Overall, 127 articles were analysed.

Results During the 5 year interval from 2015 to 2020, significantly more drugs were approved after phase III, and occasionally after phase II, trials than between 2000 and 2005 ( $p=0.002)$. Furthermore, there was a significant time difference $(\mathrm{p}=0.00001)$ indicating an increasingly briefer time interval between the publication of phase I and phase III results in the last few years.

Discussion Due to novel therapeutic approaches, numerous new drugs in lung oncology were approved. This has improved symptoms and prognoses in patients with advanced lung cancer. However, faster approval could make it difficult to scrutinise new options regarding safety and efficacy with sufficient diligence.

\section{Introduction}

The incidence of all cancer types in Europe continues to increase from 2.1 million cases in 1995 to 3.1 million cases in 2018. This corresponds to an increment rate of around 50\% in one generation. In the European Union (EU) more than 312000 people were diagnosed with lung cancer in 2018. Lung cancer causes approximately $20 \%$ of all cancer deaths in the EU [1-3]. In 2018, lung cancer accounted for $15 \%$ of all newly diagnosed malignancies in men. Lung cancer remains the most fatal cancer among men $[4,5]$. Following a rise in cigarette smoking among women, lung cancer incidence increased from $10 \%$ in the late 1990 s to $14 \%$ in 2018 . Thus, nowadays lung cancer is the second most common fatal cancer type among women after breast cancer [6, 7].

In the last two decades, there has been significant progress in the treatment of lung cancer due to substantial breakthroughs in the understanding of molecular pathology and cancer immunology [8, 9]. At the turn of the millennium, platinum-based chemotherapy was the gold standard in lung cancer treatment. 
Starting with the IPASS trial, compounds targeting the endothelial growth factor receptor (EGFR) (gefitinib and erlotinib) and other molecules targeting driver mutations have been developed. Fluorescence in situ hybridisation or immune histochemistry and, recently, the possibility of RNA-next generation sequencing (NGS) have made it possible to detect larger gene rearrangements, as in the ALK and ROS1 genes [10]. If a targetable mutation can be detected in an individual lung cancer patient, therapy can be initiated with an oral tyrosine kinase inhibitor (TKI) that precisely addresses this mutation. Crizotinib was the first approved TKI to be used for first-line therapy for advanced ROS1 and ALK-positive nonsmall cell lung cancer (NSCLC) [11].

Checkpoint inhibition (CPI) has been successfully introduced into lung cancer treatment since 2015. CPI started with second-line therapy for metastatic NSCLC but rapidly broadened its scope to first-line therapy for NSCLC, combination strategies, extensive stage small cell lung cancer (SCLC) and the earlier stages of NSCLC.

All of these new therapeutic approaches resulted in significant improvements in survival [8]. This review addresses the essential key publications that have led to the approval of new drugs for the treatment of lung cancer. We address the time trends of new developments in lung cancer and the duration from first clinical evidence to approval.

\section{Methods}

Using the electronic databases the Cochrane Library, MEDLINE (via PubMed) and the European Union Clinical Trial Register, a systematic search was performed from inception to 1 June 2020. In addition, a desktop search was implemented, and the reference lists of published full-text articles and systematic reviews were manually scanned for pertinent studies. Based on our clinical trial publications, we also searched for additional literature on the approved drugs like updates, health-related quality of life (HRQoL) research in clinical trials and biomarker analyses.

The search terms were: "lung cancer” (OR “canceration” OR “cancerized” OR “cancerous” OR "neoplasms” OR "non-small cell lung” OR "non-small cell lung cancer” OR "non-small-cell carcinoma” OR “small cell lung cancer”) AND “metastatic” OR advanced” AND “clinical trial phase I” OR "phase II" OR “phase III” AND “approval” (OR “approved” OR “approving” AND “clinical trial” OR “clinical trials as topic"). These terms were combined to search through titles, abstracts and keywords. After selecting articles, we merged the results from the three databases and eliminated duplicates. The time range for our research was defined as 1 January 2000 to 1 May 2020. The database searches were limited to English language publications, independent of country of origin.

The list of publications was independently reviewed by two authors (A. Schiwitza, L. Sahovic) using the following inclusion criteria: a clinical trial in phase I, II or III; EMA approved drugs between 1 January 2000 and 1 May 2020; the inclusion of details on the study population characteristics, interventions and results. The Preferred Reporting Items for Systematic Reviews and Meta-analysis (PRISMA) flowchart of the article selection process is depicted in figure 1 . Any discrepancies were resolved by a third reviewer (A. Rittmeyer). Information on studies was assembled in a table and checked independently by A. Rittmeyer.

Pearson's chi-square test was performed to detect whether there was a statistically significant difference regarding the number of approvals in different 5-year periods within the substance groups.

We defined as key publications those publications that led to drug approvals and distinguished speed and pace. We defined speed as the number of publications per time. Pace was defined as time from first clinical results, i.e. phase I results to publication of the key phase III publication leading to approval. We calculated pace, $\Delta t$, between the publication of phase I and phase III results for each compound approved. With the statsmodel library we performed a linear regression on the data.

To identify if the sample size of the studies follows a linear trend in time, we performed a linear regression to infer the parameters and the diagnostics. Figure 2 shows sample size plotted against time and the estimated regression line. We used Python 3.7.3, NumPy 1.17.3 and statsmodel 0.10 .2 for our computations of the fits.

For conduct and reporting of this systematic review, we followed the PRISMA statement [12]. The completed PRISMA-p checklist is available in Supplementary tables S1a and S1b. 

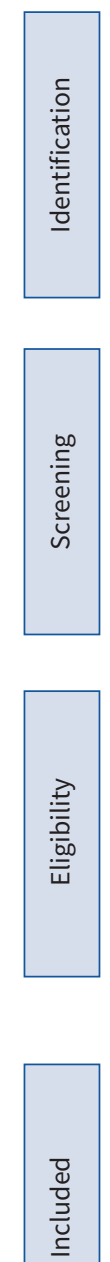

Potentially relevant records $(n=883)$

PubMed $(n=378)$

Cochrane $(n=67)$

European Union Clinical Trials Register ( $n=438)$

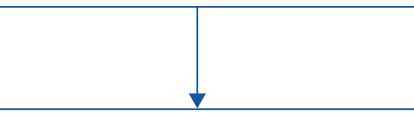

Records after duplicates removed $(n=443)$

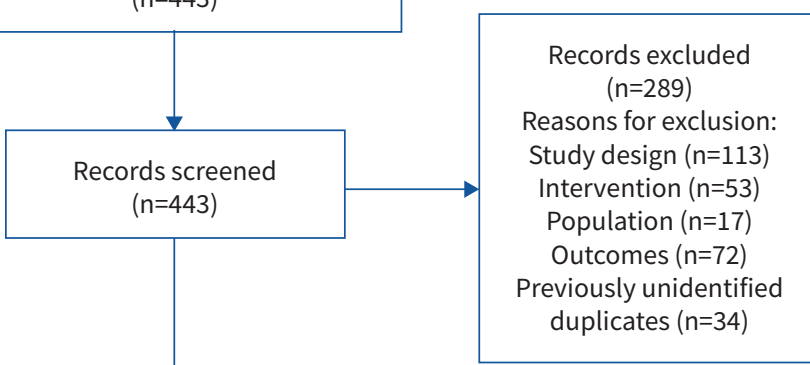

Full-text articles excluded $(n=51)$

Study design $(n=32)$ Intervention $(n=19)$

FIGURE 1 PRISMA flow diagram.

Results

Initially, 883 potentially relevant records were identified. After the duplicates were deleted and the existing articles were checked for importance, 443 relevant publications remained. These were checked for eligibility, and 103 articles met our inclusion criteria. A desktop search, including the reviews of the bibliographic reference lists of related literature review articles, yielded 24 additional publications. Thus, we identified 127 unique records for our systematic review (figure 1).

If phase III trials were published after 1 January 2000 but their connected phase I trials had been published prior to this date, the phase I publications were still included in this review.

In the last 20 years, 27 individual active compounds and 10 combination therapies for advanced lung cancer have been approved by EMA (tables 1 and 2).

Between 2000 and 2005, three drugs had been approved, including two cytotoxic drugs, docetaxel and pemetrexed, and one of the first targeted drugs, namely erlotinib, a selective inhibitor of the epidermal growth factor (EGF) tyrosine kinase domain receptor. The latter was approved for NSCLC in Europe in 2005, but at that time without restrictions, for example, companion diagnostics to detect EGFR mutations (figure 2).

In the following 5 years, three targeted agents were approved. Between 2011 and 2015 the number of approved targeted drugs increased from three to five approvals. Furthermore, nivolumab was the first 


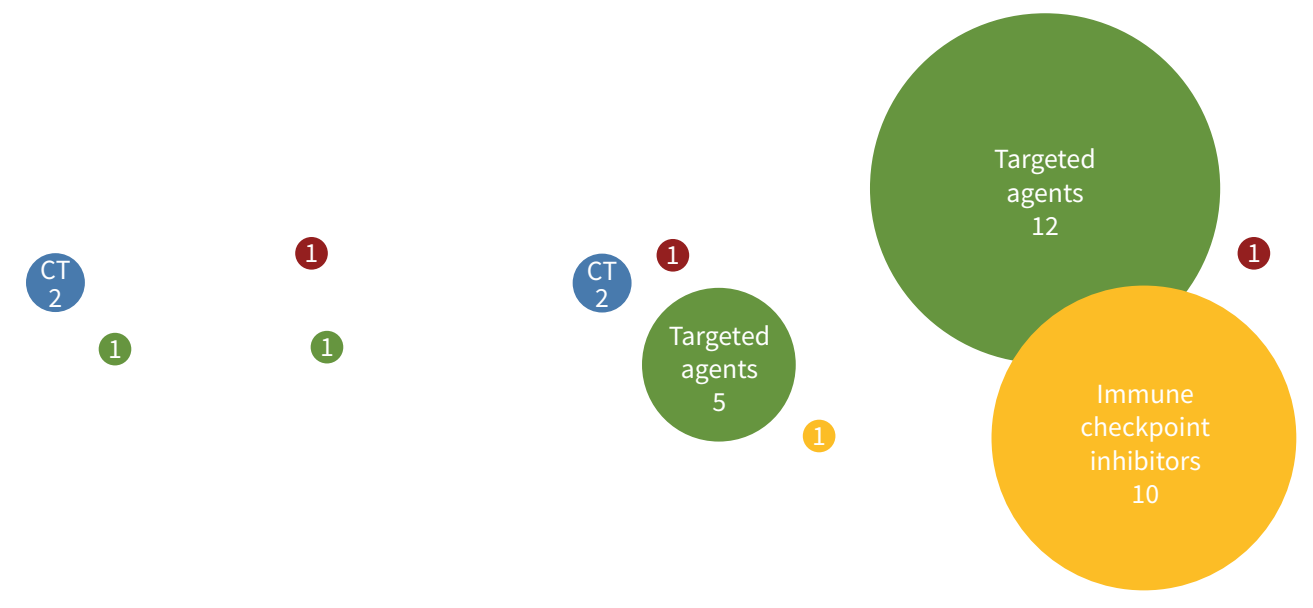

FIGURE 2 Numbers representing European Medicines Agency approved drugs within their substance class in lung oncology. Blue: chemotherapy (CT); green: targeted agents (tyrosine kinase inhibitors); red: VEGF-inhibitors; yellow: immune checkpoint inhibitors. VEGF: vascular endothelial growth factor.

checkpoint inhibitor to be approved. In the most recent 5 years, 23 new drugs for lung cancer were approved, including several drug combinations. Among them, primarily combinations of checkpoint inhibitors with standard chemotherapy according to lung cancer guidelines were approved. In addition, no new cytostatic therapy has received approval in the past 5 years. During the 5 year interval from 20152020 , significantly more drugs were approved than in any other 5 year interval before $(p=0.002)$ (Supplementary table S1c).

Figure 2 shows the development of approvals over the last two decades in 5 years intervals.

Most drugs were approved following large phase III trials. However, EMA has also approved several drugs following phase II trials (table 1), typically using median overall survival (MOS) and progression free survival (PFS) as primary end-points, with a few trials using objective response rate (ORR).

When looking at sample size and time of publication only for TKIs, decreasing sample sizes over time were detected ( $\mathrm{p}=0.0116$ ) (figure 3 ). If we excluded the two first publications on TKIs from the analysis, the sample sizes for TKI trials did not change over time. Neither combinations nor other single drugs showed a change in sample size throughout the last 20 years.

The intervals between publications of phase I data and phase III trials has declined over time $(\mathrm{p}=0.00001)$ (figure 2). For the three drugs, pemetrexed, docetaxel and erlotinib, that were approved between 2000 and 2006, the average time between phase I and phase III amounted to 69.3 months. In summary, for the first five drugs approved for lung cancer after the millennium, the average time between phase I and phase III amounted to 73.6 months. In comparison, the release of phase III after phase I of the latest three drugs took 23.7 months, and for the last five approved drugs, 18.8 months (figure 4).

This change can also be observed with drug combinations. Phase III pemetrexed/cisplatin results were published 105 months after phase I. For atezolizumab/nabpaclitaxel/carboplatin, results were published 10 months after phase I (table 1).

Another approach to shorten the period of time from phase I trials to phase III trials is to include phase I as a run-in phase into a phase III trial, as was done for the drug combination atezolizumab/carboplatin/ etoposide in SCLC.

On occasions, phase I results were published after phase III trials, as for the drug combinations pembrolizumab/pemetrexed/platinum, atezolizumab/paclitaxel/carboplatin/bevacizumab, atezolizumab/ carboplatin/etoposide and pembrolizumab/(nab)paclitaxel/carboplatin. 
TABLE 1 Approved drugs in lung oncology, 2000-2020

\begin{tabular}{|c|c|c|c|c|c|c|c|c|c|c|c|}
\hline Chemical name & $\begin{array}{l}\text { Line of } \\
\text { therapy }\end{array}$ & $\begin{array}{c}\text { Phase I trial } \\
\text { (first } \\
\text { author } \\
\text { [ref.]) }\end{array}$ & $\begin{array}{l}\text { Trial leading to } \\
\text { approval } \\
\text { (first author [ref.]) }\end{array}$ & $\begin{array}{l}\text { Sample } \\
\text { size }\end{array}$ & $\begin{array}{l}\text { EMA } \\
\text { approval } \\
\text { date }\end{array}$ & $\begin{array}{l}\text { Approval } \\
\text { trial phase }\end{array}$ & Histology & Class & $\begin{array}{l}\text { Monoclonal } \\
\text { antibody }\end{array}$ & $\begin{array}{c}\text { Route of } \\
\text { administration }\end{array}$ & $\begin{array}{l}\text { Primary end-point } \\
\text { trial leading to } \\
\text { approval }\end{array}$ \\
\hline Docetaxel & Second & EXTRA [13] & SHEPHERD [14] & $n=103$ & $\begin{array}{c}6 \text { February } \\
2000\end{array}$ & III & NSCLC & Chemotherapy & No & i.v. & MOS \\
\hline Pemetrexed & Second & $\begin{array}{l}\text { McDonALD } \\
{[15]}\end{array}$ & HanNA [16] & $\mathrm{n}=571$ & $\begin{array}{c}22 \\
\text { September } \\
2004\end{array}$ & III & nsNSCLC & Chemotherapy & No & i.v. & MOS \\
\hline Erlotinib & Second & HIDALGO [17] & SHEPHERD [18] & $n=731$ & 27 June 2005 & III & NSCLC & Targeted agent ${ }^{\natural}$ & No & Oral & MOS \\
\hline Gefitinib & Any & BASELGA [19] & Мок [20] & $\mathrm{n}=1217$ & 1 July 2009 & III & nsNSCLC & Targeted agent & No & Oral & PFS \\
\hline Erlotinib & First & HIDALGO [17] & Rosell [21] & $\mathrm{n}=174$ & $\begin{array}{c}1 \text { November } \\
2011\end{array}$ & III & nsNSCLC & Targeted agent & No & Oral & PFS \\
\hline Crizotinib & Second & KWAK [22] & SHAW [11] & $n=347$ & $\begin{array}{l}24 \text { October } \\
2012\end{array}$ & III & $\begin{array}{l}\text { ROS1/ALK } \\
+\mathrm{NSCLC}^{+}\end{array}$ & Targeted agent & No & Oral & PFS \\
\hline Afatinib & First & $Y_{A P}[23]$ & Sequist [24] & $n=345$ & $\begin{array}{c}25 \\
\text { September } \\
2013\end{array}$ & III & $\begin{array}{c}\text { EGFR } \\
+ \text { nsNSCLC }\end{array}$ & Targeted agent & No & Oral & PFS \\
\hline Ceritinib & Second & SHAW [25] & SHAW [26] & $n=231$ & 8 May 2015 & III & ALK+NSCLC & Targeted agent & No & Oral & PFS \\
\hline Nivolumab & Second & BRAHMER [27] & BRAhMER [28] & $n=272$ & 20 July 2015 & III & SqNSCLC & $\begin{array}{l}\text { Immune } \\
\text { checkpoint }\end{array}$ & Yes & i.v. & MOS \\
\hline Crizotinib & First & KWAK [22] & SoLomon [29] & $n=343$ & $\begin{array}{c}24 \text { November } \\
2015\end{array}$ & III & $\begin{array}{l}\text { ROS1/ALK } \\
+\mathrm{NSCLC}^{+}\end{array}$ & Targeted agent & No & Oral & PFS \\
\hline Osimertinib & Second & CROSS [30] & Mok [31] & $n=419$ & $\begin{array}{l}3 \text { February } \\
2016\end{array}$ & III & $\begin{array}{l}\text { EGFR M } \\
+ \text { NSCLC }\end{array}$ & Targeted agent & No & Oral & PFS \\
\hline Nivolumab & Second & BRAhmer [27] & BORGHAEI [32] & $n=582$ & 6 April 2016 & III & nsNSCLC & $\begin{array}{l}\text { Immune } \\
\text { checkpoint }\end{array}$ & Yes & i.v. & MOS \\
\hline Afatinib & Second & Yap [23] & THONGPRASERT [33] & $n=60$ & 7 April 2016 & III & $\begin{array}{c}\text { EGFR } \\
+\mathrm{NSCLC}\end{array}$ & Targeted agent & No & Oral & ORR \\
\hline Pembrolizumab & Second & GARON [34] & HERBST [35] & $n=1034$ & $\begin{array}{l}2 \text { August } \\
2016\end{array}$ & III & $\begin{array}{l}\text { PD-L1 >1\% } \\
+ \text { NSCLC }\end{array}$ & $\begin{array}{l}\text { Immune } \\
\text { checkpoint }\end{array}$ & Yes & i.v. & MOS PFS ${ }^{\S}$ \\
\hline Pembrolizumab & First & GARON [34] & ReCK [36] & $n=305$ & $\begin{array}{l}31 \text { January } \\
2017\end{array}$ & III & $\begin{array}{l}\text { PD-L1 >50\% } \\
\quad \text { NSCLC }\end{array}$ & $\begin{array}{l}\text { Immune } \\
\text { checkpoint }\end{array}$ & Yes & i.v. & PFS \\
\hline Alectinib & Second & Seto [37] & SHAW [38] & $n=87$ & $\begin{array}{l}21 \text { February } \\
2017\end{array}$ & II & ALK+NSCLC & Targeted agent & No & Oral & ORR \\
\hline $\begin{array}{l}\text { Dabrafenib/ } \\
\text { trametinib }\end{array}$ & Any & FALCHOOK [39] & Planchard [40] & $n=36$ & 3 April 2017 & II & $\begin{array}{l}\text { BRAf V600E } \\
+ \text { NSCLC }\end{array}$ & Targeted agent & No & Oral & ORR \\
\hline Atezolizumab & Second & HeRBSt [41] & RItTMEYER [42] & $n=1125$ & $\begin{array}{c}22 \\
\text { September } \\
2017\end{array}$ & III & NSCLC & $\begin{array}{l}\text { Immune } \\
\text { checkpoint }\end{array}$ & Yes & i.v. & $\operatorname{MOS}^{f}$ \\
\hline Alectinib & First & Seto [37] & Peters [43] & $n=303$ & $\begin{array}{l}21 \text { December } \\
2017\end{array}$ & III & ALK+NSCLC & Targeted agent & No & Oral & PFS \\
\hline Osimertinib & First & CROSS [30] & SORIA [44] & $n=556$ & 8 June 2018 & III & $\begin{array}{l}\text { EGFR M } \\
+ \text { NSCLC }\end{array}$ & Targeted agent & No & Oral & PFS \\
\hline Durvalumab & Consolidation & AntonIA [45] & ANTONIA [46] & $n=709$ & 27 July 2018 & III & NSCLC & $\begin{array}{l}\text { Immune } \\
\text { checkpoint }\end{array}$ & Yes & i.v. & MOS $\mathrm{PFS}^{\S}$ \\
\hline
\end{tabular}




\begin{tabular}{|c|c|c|c|c|c|c|c|c|c|c|c|}
\hline Chemical name & $\begin{array}{l}\text { Line of } \\
\text { therapy }\end{array}$ & $\begin{array}{l}\text { Phase I trial } \\
\text { (first } \\
\text { author } \\
\text { [ref.]) }\end{array}$ & $\begin{array}{c}\text { Trial leading to } \\
\text { approval } \\
\text { (first author [ref.]) }\end{array}$ & $\begin{array}{l}\text { Sample } \\
\text { size }\end{array}$ & $\begin{array}{l}\text { EMA } \\
\text { approval } \\
\text { date }\end{array}$ & $\begin{array}{l}\text { Approval } \\
\text { trial phase }\end{array}$ & Histology & Class & $\begin{array}{l}\text { Monoclonal } \\
\text { antibody }\end{array}$ & $\begin{array}{c}\text { Route of } \\
\text { administration }\end{array}$ & $\begin{array}{c}\text { Primary end-point } \\
\text { trial leading to } \\
\text { approval }\end{array}$ \\
\hline Brigatinib & Second & $\begin{array}{c}\text { Gettinger } \\
{[47]}\end{array}$ & CAMidge [48] & $n=275$ & $\begin{array}{c}27 \text { November } \\
2018\end{array}$ & III & ALK+ NSCLC & Targeted agent & No & Oral & PFS \\
\hline Dacomitinib & First & $\begin{array}{c}\text { TAKAHASHI } \\
{[49]}\end{array}$ & Wu [50] & $n=452$ & 3 April 2019 & III & $\begin{array}{l}\text { EGFR M } \\
+ \text { NSCLC }\end{array}$ & Targeted agent & No & Oral & PFS \\
\hline Lorlatinib & Second & SHAW [51] & SoLomon [52] & $n=276$ & 7 May 2019 & II & ALK+NSCLC & Targeted agent & No & Oral & $\mathrm{ORR}^{f}$ \\
\hline Larotrectinib & Any & DRILON [53] & DRILON [53] & $n=55$ & $\begin{array}{c}23 \\
\text { September } \\
2019\end{array}$ & ॥ & $\begin{array}{c}\text { NTRK } \\
+ \text { NSCLC }\end{array}$ & Targeted agent & No & Oral & ORR \\
\hline Brigatinib & First & $\begin{array}{c}\text { Gettinger } \\
{[47]}\end{array}$ & HUBERT [54] & $n=222$ & 6 April 2020 & III & ALK+ NSCLC & Targeted agent & No & Oral & ORR \\
\hline
\end{tabular}

\#: first approval was granted for any NSCLC but after subgroup analyses of three trials employing pemetrexed the approval was restricted to nsNSCLC for lack of efficiency in squamous NSCLC [62]. ": although later approved as a targeted agent, the drug was first approved for any NSCLC without any mandatory companion diagnostic to detect a targetable mutation. ${ }^{+}$: Pfizer [55]. $:$: for details please refer to full publication as alpha was split applying different statistical plans. ${ }^{f}$ : and intracranial tumour response. EMA: European Medicines Agency; NSCLC: nonsmall cell lung cancer; MOS: median overall survival; nsNSCLC: nonsquamous nonsmall cell lung cancer; PFS: progression free survival; ALK: anaplastic lymphoma kinase; EGFR: epidermal growth factor receptor; SqNSCLC: squamous nonsmall cell lung cancer; EGFR M+NSCLC: EGFR mutation positive NSCLC; ORR: objective response rate according to RECIST 1.1 
TABLE 2 Approved drug combinations in lung oncology, 2000-2020

\begin{tabular}{|c|c|c|c|c|c|c|c|c|c|c|c|}
\hline Chemical name & $\begin{array}{l}\text { Line of } \\
\text { therapy }\end{array}$ & Phase I & $\begin{array}{l}\text { Trial leading } \\
\text { to approval }\end{array}$ & $\begin{array}{l}\text { Sample } \\
\text { size }\end{array}$ & $\begin{array}{l}\text { EMA approval } \\
\text { date }\end{array}$ & $\begin{array}{l}\text { Approval } \\
\text { trial phase }\end{array}$ & Histology & Class & $\begin{array}{l}\text { Monoclonal } \\
\text { antibody }\end{array}$ & $\begin{array}{c}\text { Route of } \\
\text { administration }\end{array}$ & $\begin{array}{l}\text { Primary } \\
\text { end-point trial } \\
\text { leading to } \\
\text { approval }\end{array}$ \\
\hline $\begin{array}{l}\text { Bevacizumab/paclitaxel/ } \\
\text { carboplatin }\end{array}$ & First & $\begin{array}{c}\text { Willett (Phase I) } \\
\text { [56]; Johnson } \\
\text { (Phase II) [57] }\end{array}$ & SANDLER [58] & $\mathrm{n}=878$ & $\begin{array}{l}23 \text { August } \\
2007\end{array}$ & III & nsNSCLC & Targeted agent & Yes & i.v. & MOS \\
\hline Pemetrexed/cisplatin & First & THÖDtMAnN [59] & $\begin{array}{c}\text { SCAGLIOTTI } \\
\text { [60] }\end{array}$ & $n=1725$ & $\begin{array}{c}28 \text { October } \\
2011\end{array}$ & III & nsNSCLC & $\mathrm{CT} / \mathrm{CT}$ & No & i.v. & MOS \\
\hline Nintedanib/docetaxel & Second & Mross [61] & ReCK [62] & $n=1324$ & $\begin{array}{l}27 \text { November } \\
2014\end{array}$ & III & nsNSCLC & Targeted agent & No & Oral & PFS \\
\hline nabPaclitaxel/carboplatin & First & RIzvi [63] & SocINSKI [64] & $n=1052$ & 2 March 2015 & III & SqNSCLC & Chemotherapy & No & i.v. & ORR \\
\hline Docetaxel/ramucirumab & Second & SpRATLIN [65] & GARON [66] & $n=1825$ & $\begin{array}{l}28 \text { January } \\
2016\end{array}$ & III & nsNSCLC & Targeted agent & Yes & i.v. & MOS \\
\hline $\begin{array}{l}\text { Gemcitabine/cisplatin/ } \\
\text { necitumumab }\end{array}$ & First & Kuenen [67] & THATCHER [68] & $n=1093$ & $\begin{array}{l}24 \text { February } \\
2016\end{array}$ & III & SqNSCLC & Targeted agent & Yes & i.v. & MOS \\
\hline $\begin{array}{l}\text { Pembrolizumab/(nab) } \\
\text { Paclitaxel/carboplatin }\end{array}$ & First & GadGEel [69] & Paz-Ares [70] & $n=559$ & $\begin{array}{l}14 \text { March } \\
2019\end{array}$ & III & SqNSCLC & $\mathrm{ICP} / \mathrm{CT} / \mathrm{CT}$ & Yes & i.v. & MOS PFS \\
\hline $\begin{array}{l}\text { Pembrolizumab/pemetrexed/ } \\
\text { platin }\end{array}$ & First & Gadgeel [69] & GANDHI [71] & $n=616$ & $\begin{array}{l}15 \text { March } \\
2019\end{array}$ & III & nsNSCLC & $\mathrm{ICP} / \mathrm{CT} / \mathrm{CT}$ & Yes & i.v. & MOS PFS \\
\hline $\begin{array}{l}\text { Atezolizumab/carboplatin/ } \\
\text { etoposide }\end{array}$ & First & HORN [72] & HORN [72] & $\mathrm{n}=403$ & $\begin{array}{l}6 \text { September } \\
2019\end{array}$ & III & SCLC & $\mathrm{ICP} / \mathrm{CT} / \mathrm{CT}$ & Yes & i.v. & MOS PFS \\
\hline $\begin{array}{l}\text { Atezolizumab/nab-Paclitaxel/ } \\
\text { carboplatin }\end{array}$ & First & Liv [73] & WEST [74] & $n=723$ & $\begin{array}{l}6 \text { September } \\
2019\end{array}$ & III & nsNSCLC & $\mathrm{ICP} / \mathrm{CT} / \mathrm{CT}$ & Yes & i.v. & MOS PFS \\
\hline $\begin{array}{l}\text { Atezolizumab/paclitaxel/ } \\
\text { carboplatin/bevacizumab }\end{array}$ & First & LIU [73] & SocINSKI [75] & $n=692$ & $\begin{array}{l}6 \text { September } \\
2019\end{array}$ & III & nsNSCLC & ICP/CT/CT/TA & Yes & i.v. & MOS PFS \\
\hline
\end{tabular}

EMA: European Medicines Agency; nsNSCLC: nonsquamous nonsmall cell lung cancer; MOS: median overall survival; CT: chemotherapy; PFS: progression free survival; SqNSCLC: squamous nonsmall cell lung cancer; ORR: objective response rate; ICP: immune checkpoint; SCLC: small cell lung cancer; TA: targeted agent 


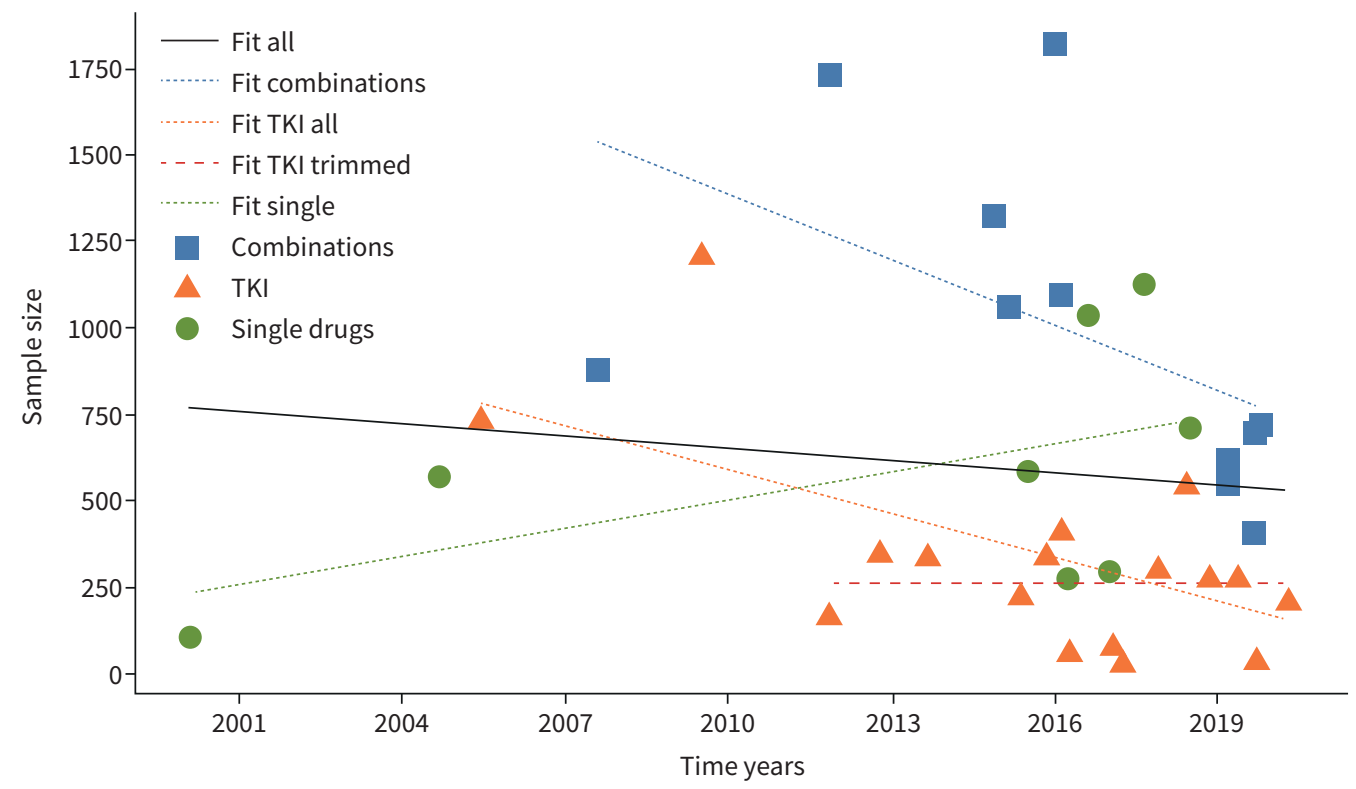

FIGURE 3 Correlation of sample size and date of publication regarding approved combinations (blue line and squares), TKIs (orange line and triangles) and single drugs except TKIs (green line and dots). The black line shows the correlation of sample size and date for all approved drugs and combinations. TKI trimmed (red line): shows data without the two first trials for erlotinib and gefitinib [18, 20]. TKI: tyrosine kinase inhibitor.

\section{Discussion}

This review demonstrates that key publications in lung cancer have gained speed and pace throughout the last 20 years.

With the advancement of cancer medicine, drug focus has changed, from classical chemotherapy "poisoning” cancer cells but also noncancer cells, to a more targeted approach.

As a first step in this direction, drugs targeting the vascular endothelial growth factor (VEGF)-pathway were developed leading to the approval of three drugs over more than 10 years [32, 53, 66]. However, the

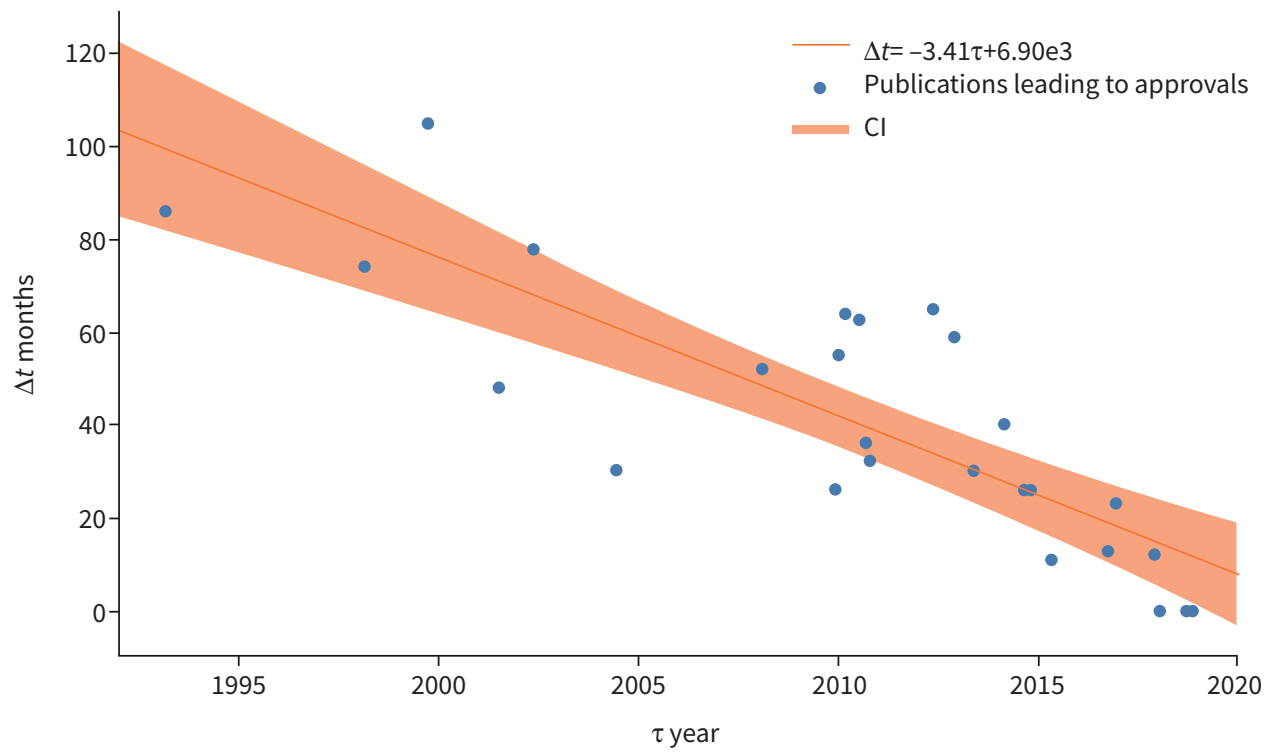

FIGURE 4 Time intervals between the publications of linked phase I and phase III trials. Correlation coefficient $r=-0.82303 ; p=0.00001$. Estimated rate over time shown along with a $95 \%$ credible region. 
clinical effect of VEGF-compounds remained rather small and many drugs failed to show any significant improvement [76-78]. Another problem of targeting the VEGF-pathway is that the search for biomarkers helping to tailor VEGF-directed therapy has still not led to any predictive tool.

The importance of predictive tools can be highlighted by the "EGFR story". To target the EGFR seemed reasonable in the beginning of the century, leading to compounds such as erlotinib and gefitinib as TKIs targeting the intracellular EGFR tyrosine kinase. To target the extracellular part of the EGFR, antibodies, such as cetuximab, were developed. However, apart from the use of erlotinib in second-line therapy, none of those drugs showed any significant improvements [79-82]. This only changed when the importance of activating EGFR mutations was detected [83], leading to the pivotal IPASS trial [20, 84]. After having learned the EGFR lesson, the speed of approvals for targeted drugs increased. In this respect, the detection of anaplastic lymphoma kinase (ALK) rearrangements as a driver mutation inducing lung cancer is also interesting. Crizotinib had originally been developed to target the MET-receptor and the efficacy in patients with ALK-rearrangements was detected rather incidentally [11]. Nevertheless, after all these lessons had been learned, researchers had been able to address every single driver mutation more specifically by designing compounds that match a specific target [85].

However, performing clinical trials in this setting is often challenging as the low frequency of single mutations makes it difficult to recruit sufficient numbers of patients. It is, however, questionable if a classical randomised phase III design is appropriate to prove efficacy. In particular, it seems ambiguous from an ethical point of view to create a randomised clinical trial protocol for the very first compound for a given newly detected mutation without a mandatory crossover for those patients randomised to what is considered standard of care (most often standard chemotherapy). These factors have led to rather small trials and to approvals on the basis of phase I/II trials, as was the case for larotrectinib which was designed for NTRK fusion mutations that occur in no more than $0.1 \%$ of patients with NSCLC [53, 86].

Although the number of driver mutations is increasing every year, the number of patients who benefit from these innovations stays rather low at about $10 \%$ of patients with nonsquamous NSCLC. Thus the impact of the introduction of checkpoint inhibitors was much more profound as, in rapid succession, all patients with NSCLC (including squamous cell lung cancer) could be treated with cancer immunotherapy. Today, any patient with stage IV lung cancer, regardless of histology and PD-L1 expression (even including patients with SCLC), can be treated with a checkpoint inhibitor as a first-line therapy. The number of publications in the field of lung cancer immunotherapy and checkpoint inhibitions has skyrocketed in the last few years, leading in 2015 to the first approval for nivolumab as a monotherapy in second-line lung cancer treatment and expanding ever since. In this setting, the classical randomised phase III design leading to approval seems appropriate as the number of patients that could be enrolled into a trial is rather high.

Looking for alternative explanations to the increasing speed of lung cancer key publications we could show that the time from phase I to phase III trials has been reduced significantly ("pace”). In this context it seems striking that some phase I trials have been published after the phase III results [44, 70-72, 75]. This highlights what the market, represented by the high impact scientific journals, considers worth publishing and when the first phase I trial of nivolumab was published in the Journal of Clinical Oncology in 2010 [27], none of the following phase I experiences could ever get close.

Another explanation that we found not to be relevant for picking up speed was the suggestion that the sample size of trials leading to approval has been reduced over time. We could show a trend of decreasing sample size for TKI trials. However, this was mainly because the oldest two trials, investigating erlotinib without biomarkers and gefitinib in the IPASS trial, proved the importance of predictive tests in the newly discovered world of lung cancer driver mutations for the first time ever. For the more recent TKI trials, and for all other drugs or combinations, no correlations regarding sample size and date of publication could be detected.

It is our conviction that the increasing speed of key lung cancer publications leading to approvals reflects the pace of science that has improved the landscape of lung cancer, especially in terms of patient survival [8]. In 2000, before the approval of docetaxel, the MOS of lung cancer (NSCLC) patients that were deemed fit to be treated with cisplatin was about 8 months [87]. Today, this MOS has doubled in patients without driver mutations and without high PD-L1 expression. In subgroups that can include up to one-third of all patients, such as a tumour proportion score (TPS) $>50 \%$, MOS has increased to more than 2 years. What seems even more important for individual patients is the fact that about $15 \%$ of unselected patients 
survive more than 5 years, which would have been close to impossible in 2000 [86], and in the PD-L1-high subgroup this is possibly even higher. Survival improval is even more pronounced in patients with driver mutations showing a MOS ranging from 27 [88] to 51 months [89].

The achievements in lung cancer therapy throughout the last 20 years have been extraordinary and we fully appreciate the arrival of so many new treatment options. However, in line with others we think that there are some caveats that have to be considered [90].

For example, the approval of larotrectinib was based on just 55 patients, including only four patients with lung cancer. It is certainly helpful to have another option for those very few patients harbouring this rearrangement; however, do we really know that larotrectinib is the best choice in first-line treatment? How low can the number of patients included be to convince us that a drug is the best choice in other driver mutations? Is the combination of dabrafenib/trametinib, approved based on two single-arm phase II trials including 57 and 36 patients [40, 90], favourable compared with a combination of a CPI and chemotherapy or CPI alone in patients with a high TPS? Only recently, some researchers have started publishing results of patients harbouring driver mutations treated with checkpoint inhibitors revealing that in some patients with KRAS, MET and BRAF mutations, CPIs tend to have an effect close to the effects seen in patients without any mutation whereas in patients with classical nonsmoker mutations CPIs tend to have little effect $[91,92]$. What can be accepted as a proof of superior efficacy regarding newly tested drugs, such as, for example, the compound targeting G12C-KRAS-mutations?

Is full-dose chemotherapy combined with CPI really the best choice in first-line treatment of metastatic NSCLC given the fact that phase I experiences with pembrolizumab include 74 patients and with atezolizumab 76 patients? In both phase I trials, patients were treated in three arms with different chemotherapies at full dose, leaving only 25 patients for each arm and lower doses of chemotherapy which have never been tested.

We should be careful to jump to conclusions too early as we have seen very convincing phase II results in the past, for example for Onartuzumab, with very disappointing phase III results [91, 93-95].

End-points for clinical trials intended to file for approval should be very carefully selected and preferably discussed with the authorities in advance. These primary end-points should reflect the supposed benefit of the new drug as well as possible. When choices were few MOS has always been the end-point of choice. However, particularly in driver mutated lung cancer, in which several lines of extremely efficacious drugs can be applied sequentially, PFS may often be an adequate choice. ORR, even by blinded independent central review, seems challenging in our opinion and should rather not be used for approval.

We listed the primary end-points of the trials leading to approval in table 1 . However, we did not go into detail about the secondary end-points of these trials as a wide variety of secondary end-points had been employed. Additionally, secondary end-points can only lead to new hypotheses as the alpha power of each trial is restricted to the primary end-points.

One limitation of our study is that we have arbitrarily chosen four 5-year periods for the analyses of time trends. Furthermore, the included publications were not scored according to the risk of bias within the study as suggested by PRISMA (Supplementary table 1). However, we feel that reporting bias would have no impact on our findings as we do not address effectiveness of therapy. Another limitation is that we focused on positive results leading to approval only. Negative results could also be considered as key publications. However, as many negative results have not been published in peer reviewed journals at all, it seemed favourable to us to concentrate on positive trials as they have truly changed clinical practice.

Finally, it seems important to mention that progress for the treatment of lung cancer has not been restricted to drugs, and advances have also been made in diagnostics and multimodal therapeutic approaches, which we consider to be very important and evolving topics; although ones that would have gone beyond the scope of this review and which should be addressed separately.

In conclusion, we have witnessed two decades of remarkable advances regarding therapy of metastatic (and locally advanced) lung cancer with increasing speed and pace. However we should be aware that new questions arise that should be carefully considered when new drugs are approved. Many details need to be considered in the process of any new pharmacological trial. Foremost, it is essential to continuously ensure the best possible safety in clinical trials, even in an expeditious growing market. 
Provenance: Commissioned article, peer reviewed.

Previous articles in this series: No. 1: Eichhorn F, Winter H. How to handle oligometastatic disease in nonsmall cell lung cancer. Eur Respir Rev 30: 2021; 200234. No. 2: Asciak R, George V, Rahmna NM. Update on biology and management of mesothelioma. Eur Respir Rev 30: 2021; 200226. No. 3: Finazzi T, Schneiders FL, Senan S. Developments in radiation techniques for thoracic malignancies. Eur Respir Rev 30: 2021; 200224. No. 4: Huber RM, Kauffmann-Guerrero D, Hoffmann H, et al. New developments in locally advanced nonsmall cell lung cancer. Eur Respir Rev 30: 2021; 200227.

Author contributions: All authors focused on the conception and design. All authors were dedicated to the collection and assembly of data, data analysis and interpretation, manuscript writing, final approval of manuscript. All authors are accountable for all aspects of the work.

Conflict of interest: A. Rittmeyer reports grants from EliLilly, BMS, Boehringer Ingelheim, AstraZeneca, MSD, Pfizer, AbbVie, Novartis and Roche, outside the submitted work. A. Schiwitza has nothing to disclose. L. Sahovic has nothing to disclose. B. Eul has nothing to disclose. S. Andreas reports grants and personal fees from Boehringer Ingelheim, personal fees from Novartis, AstraZeneca, GSK, Chiesi and Merini, and grants from Pfizer, outside the submitted work.

\section{References}

1 Ferlay J, Colombet M, Soerjomataram I, et al. Cancer incidence and mortality patterns in Europe: estimates for 40 countries and 25 major cancers in 2018. Eur J Cancer 2018; 103: 356-387.

2 Ferlay J, Parkin DM, Steliarova-Foucher E. Estimates of cancer incidence and mortality in Europe in 2008. Eur J Cancer 2010; 46: 765-781.

3 Ferlay J, Steliarova-Foucher E, Lortet-Tieulent J, et al. Cancer incidence and mortality patterns in Europe: estimates for 40 countries in 2012. Eur J Cancer 2013; 49: 1374-1403.

4 Bray F, Sankila R, Ferlay J, et al. Estimates of cancer incidence and mortality in Europe in 1995. Eur J Cancer 2002; 38: 99-166.

5 ECIS - European Cancer Information System. Incidence and mortality estimates 2018. Brussels, ECIS. https:// ecis.jrc.ec.europa.eu/ Date last accessed 31 May, 2020

6 Egleston BL, Meireles SI, Flieder DB, et al. Population-based trends in lung cancer incidence in women. Semin Oncol 2009; 36: 506-515.

7 European Institute of Women's Health. Policy brief: Women and smoking in the EU 2013. Geneva, World Health Organization. www.euro.who.int/_data/assets/pdf_file/0006/318147/EWHR16_interactive2.pdf Date last assessed: May 31, 2020.

8 Howlader N, Forjaz G, Mooradian MJ, et al. The effect of advances in lung-cancer treatment on population mortality. N Engl J Med 2020; 383: 640-649.

9 Garon EB, Hellmann MD, Costa EC, et al. Five-year longterm overall survival for patients with advanced NSCLC treated with pembrolizumab: results from KEYNOTE-001. J Clin Oncol 2019; 37: 2518-2527.

10 Bubendorf L, Büttner R, Al-Dayel F, et al. Testing for ROS1 in non-small cell lung cancer: a review with recommendations. Virchows Arch 2016; 469: 489-503.

11 Shaw AT, Kim D-W, Nakagawa K, et al. Crizotinib versus chemotherapy in advanced ALK-positive lung cancer. N Engl J Med 2013; 368: 2385-2394.

12 Moher D, Shamseer L, Clarke M, et al. Preferred reporting items for systematic review and meta-analysis protocols (PRISMA-P) 2015 statement. Syst Rev 2015; 4: 1.

13 Extra JM, Rousseau F, Bruno R, et al. Phase I and pharmacokinetic study of Taxotere (RP 56976; NSC 628503) given as a short intravenous infusion. Cancer Res 1993; 53: 1037-1042.

14 Shepherd FA, Dancey J, Ramlau R, et al. Prospective randomized trial of docetaxel versus best supportive care in patients with non-small-cell lung cancer previously treated with platinum-based chemotherapy. $J$ Clin Oncol 2000; 18: 2095-2103.

15 McDonald AC, Vasey PA, Adams L, et al. A phase I and pharmacokinetic study of LY231514, the multitargeted antifolate. Clin Cancer Res 1998; 4: 605-610.

16 Hanna N, Shepherd FA, Fossella FV, et al. Randomized phase III trial of pemetrexed versus docetaxel in patients with non-small-cell lung cancer previously treated with chemotherapy. J Clin Oncol 2004; 22: 1589-1597.

17 Hidalgo M, Siu LL, Nemunaitis J, et al. Phase I and pharmacologic study of OSI-774, an epidermal growth factor receptor tyrosine kinase inhibitor, in patients with advanced solid malignancies. J Clin Oncol 2001; 19: 3267-3279.

18 Shepherd F, Pereira JR, Ciuleanu T, et al. Erlotinib in previously treated non-small-cell lung cancer. $N$ Engl J Med 2005; 353: 123-132. 
19 Baselga J. Targeting the epidermal growth factor receptor with tyrosine kinase inhibitors: small molecules, big hopes. J Clin Oncol 2002; 20: 2217-2219.

20 Mok TS, Wu Y-L, Thongprasert S, et al. Gefitinib or carboplatin-paclitaxel in pulmonary adenocarcinoma. N Engl J Med 2009; 361: 947-957.

21 Rosell R, Carcereny E, Gervais R, et al. Erlotinib versus standard chemotherapy as first-line treatment for European patients with advanced EGFR mutation-positive non-small-cell lung cancer (EURTAC): a multicentre, open-label, randomised phase 3 trial. Lancet Oncol 2012; 13: 239-246.

22 Kwak EL, Bang Y-J, Camidge DR, et al. Anaplastic lymphoma kinase inhibition in non-small-cell lung cancer. N Engl J Med 2010; 363: 1693-1703.

23 Yap TA, Vidal L, Adam J, et al. Phase I trial of the irreversible EGFR and HER2 kinase inhibitor BIBW 2992 in patients with advanced solid tumors. J Clin Oncol 2010; 28: 3965-3972.

24 Sequist LV, Yang JC-H, Yamamoto N, et al. Phase III study of afatinib or cisplatin plus pemetrexed in patients with metastatic lung adenocarcinoma with EGFR mutations. J Clin Oncol 2013; 31: 3327-3334.

25 Shaw AT, Kim D-W, Mehra R, et al. Ceritinib in ALK-rearranged non-small-cell lung Cancer. N Engl J Med 2014; 370: 1189-1197.

26 Shaw AT, Kim TM, Crinò L, et al. Ceritinib versus chemotherapy in patients with ALK-rearranged non-small-cell lung cancer previously given chemotherapy and crizotinib (ASCEND-5): a randomised, controlled, open-label, phase 3 trial. Lancet Oncol 2017; 18: 874-886.

27 Brahmer JR, Drake CG, Wollner I, et al. Phase I study of single-agent anti-programmed death-1 (MDX-1106) in refractory solid tumors: safety, clinical activity, pharmacodynamics, and immunologic correlates. J Clin Oncol 2010; 28: 3167-3175.

28 Brahmer J, Reckamp KL, Baas P, et al. Nivolumab versus docetaxel in advanced squamous-cell non-small-cell lung cancer. N Engl J Med 2015; 373: 123-135.

29 Solomon BJ, Mok T, Kim D-W, et al. First-line crizotinib versus chemotherapy in ALK-positive lung cancer. N Engl J Med 2014; 371: 2167.

30 Cross DAE, Ashton SE, Ghiorghiu S, et al. AZD9291, an irreversible EGFR TKI, overcomes T790M-mediated resistance to EGFR inhibitors in lung cancer. Cancer Discov 2014; 4: 1046-1061.

31 Mok TS, Wu Y-L, Ahn M-J, et al. Osimertinib or platinum-pemetrexed in EGFR T790M-positive lung cancer. N Engl J Med 2017; 376: 629-640.

32 Borghaei H, Paz-Ares L, Horn L, et al. Nivolumab versus docetaxel in advanced Nonsquamous non-small-cell lung cancer. N Engl J Med 2015; 373: 1627-1639.

33 Thongprasert S, Alexandru A, Schenker M, et al. 477TiP phase IV study of afatinib as second-line therapy for patients with locally advanced or metastatic non-small cell lung cancer (NSCLC) harboring common epidermal growth factor receptor (EGFR) mutations (Del19 and/or L858R). Ann Oncol 2015; 26: ix125.

34 Garon EB, Rizvi NA, Hui R, et al. Pembrolizumab for the treatment of non-small-cell lung cancer. $N$ Engl $J$ Med 2015; 372: 2018-2028.

35 Herbst RS, Baas P, Kim D-W, et al. Pembrolizumab versus docetaxel for previously treated, PD-L1-positive, advanced non-small-cell lung cancer (KEYNOTE-010): a randomised controlled trial. Lancet 2016; 387: $1540-1550$.

36 Reck M, Rodríguez-Abreu D, Robinson AG, et al. Pembrolizumab versus chemotherapy for PD-L1-positive non-small-cell lung cancer. N Engl J Med 2016; 375: 1823-1833.

37 Seto T, Kiura K, Nishio M, et al. CH5424802 (RO5424802) for patients with ALK-rearranged advanced non-small-cell lung cancer (AF-001JP study): a single-arm, open-label, phase 1-2 study. Lancet Oncol 2013; 14: 590-598.

38 Shaw AT, Gandhi L, Gadgeel S, et al. Alectinib in ALK-positive, crizotinib-resistant, non-small-cell lung cancer: a single-group, multicentre, phase 2 trial. Lancet Oncol 2016; 17: 234-242.

39 Falchook GS, Long GV, Kurzrock R, et al. Dabrafenib in patients with melanoma, untreated brain metastases, and other solid tumours: a phase 1 dose-escalation trial. Lancet 2012; 379: 1893-1901.

40 Planchard D, Smit EF, Groen HJM, et al. Dabrafenib plus trametinib in patients with previously untreated BRAFV600E-mutant metastatic non-small-cell lung cancer: an open-label, phase 2 trial. Lancet Oncol 2017; 18: 1307-1316.

41 Herbst RS, Soria J-C, Kowanetz M, et al. Predictive correlates of response to the anti-PD-L1 antibody MPDL3280A in cancer patients. Nature 2014; 515: 563-567.

42 Rittmeyer A, Barlesi F, Waterkamp D, et al. Atezolizumab versus docetaxel in patients with previously treated non-small-cell lung cancer (OAK): a phase 3, open-label, multicentre randomised controlled trial. Lancet 2017; 389: 255-265.

43 Peters S, Camidge DR, Shaw AT, et al. Alectinib versus crizotinib in untreated ALK-positive non-small-cell lung cancer. N Engl J Med 2017; 377: 829-838.

44 Soria J-C, Ohe Y, Vansteenkiste J, et al. Osimertinib in untreated EGFR-mutated advanced non-small-cell lung cancer. N Engl J Med 2018; 378: 113-125. 

patients with non-small cell lung cancer. Ann Oncol 2016; 27: 416-454.

46 Antonia SJ, Kim S-W, Spira Al, et al. Safety and clinical activity of durvalumab (MEDI4736), an anti-PD-L1 antibody, in treatment-naïve patients with advanced non-small-cell lung cancer. J Clin Oncol 2016; 34: 9029-9029.

Gettinger SN, Bazhenova LA, Langer CJ, et al. Activity and safety of brigatinib in ALK-rearranged non-small-cell lung cancer and other malignancies: a single-arm, open-label, phase 1/2 trial. Lancet Oncol 2016; 17: 1683-1696.

48 Camidge DR, Kim HR, Ahn M-J, et al. Brigatinib versus crizotinib in ALK-positive non-small-cell lung cancer. N Engl J Med 2018; 379: 2027-2039.

49 Takahashi T, Boku N, Murakami H, et al. Phase I and pharmacokinetic study of dacomitinib (PF-00299804), an oral irreversible, small molecule inhibitor of human epidermal growth factor receptor-1, -2 , and -4 tyrosine kinases, in Japanese patients with advanced solid tumors. Invest New Drugs 2012; 30: 2352-2363.

50 Wu Y-L, Cheng Y, Zhou X, et al. Dacomitinib versus gefitinib as first-line treatment for patients with EGFR-mutation-positive non-small-cell lung cancer (ARCHER 1050): a randomised, open-label, phase 3 trial. Lancet Oncol 2017; 18: 1454-1466.

51 Shaw AT, Felip E, Bauer TM, et al. Lorlatinib in non-small-cell lung cancer with ALK or ROS1 rearrangement: an international, multicentre, open-label, single-arm first-in-man phase 1 trial. Lancet Oncol 2017; 18: 1590-1599.

52 Solomon BJ, Besse B, Bauer TM, et al. Lorlatinib in patients with ALK-positive non-small-cell lung cancer: results from a global phase 2 study. Lancet Oncol 2018; 19: 1654-1667.

53 Drilon A, Laetsch TW A, Kummar S, et al. Efficacy of larotrectinib in TRK fusion-positive cancers in adults and children. N Engl J Med 2018; 378: 731-739.

54 Huber RM, Hansen KH, Rodríguez LP-A, et al. Brigatinib in crizotinib-refractory ALK+ NSCLC: 2-year follow-up on systemic and intracranial outcomes in the phase 2 alta trial. J Thorac Oncol 2020; 15: 404-415.

55 Pfizer. Xalkori ${ }^{\circledR}$ (Crizotinib) Receives Approval in European Union for the Treatment of Patients with Ros1Positive Advanced Non-Small Cell Lung Cancer. https://www.pfizer.com/news/press-release/pressreleasedetail/xalkori_crizotinib_receives_approval_in_european_union_for_the_treatment_of_patients_with_ ros1_positive_advanced_non_small_cell_lung_cancer Date last accessed: 23 April, 2021. Date last updated: August 21, 2016.

56 Willett CG, Boucher Y, di Tomaso E, et al. Direct evidence that the VEGF-specific antibody bevacizumab has antivascular effects in human rectal cancer. Nat Med 2004; 10: 145-147.

57 Johnson DH, Fehrenbacher L, Novotny WF, et al. Randomized phase II trial comparing bevacizumab plus carboplatin and paclitaxel with carboplatin and paclitaxel alone in previously untreated locally advanced or metastatic non-small-cell lung cancer. J Clin Oncol 2004; 22: 2184-2191.

58 Sandler A, Gray R, Perry MC, et al. Paclitaxel-carboplatin alone or with bevacizumab for non-small-cell lung cancer. N Engl J Med 2006; 355: 2542-2550.

59 Thödtmann R, Depenbrock H, Dumez H, et al. Clinical and pharmacokinetic phase I study of multitargeted antifolate (LY231514) in combination with cisplatin. J Clin Oncol 1999; 17: 3009-3016.

60 Scagliotti GV, Parikh P, von Pawel J, et al. Phase III study comparing cisplatin plus gemcitabine with cisplatin plus pemetrexed in chemotherapy-naive patients with advanced-stage non-small-cell lung cancer. $J$ Clin Oncol 2008; 26: 3543-3551.

61 Mross K, Stefanic M, Gmehling D, et al. Phase I study of the angiogenesis inhibitor BIBF 1120 in patients with advanced solid tumors. Clin Cancer Res 2010; 16: 311-319.

62 Reck M, Kaiser R, Mellemgaard A, et al. Docetaxel plus nintedanib versus docetaxel plus placebo in patients with previously treated non-small-cell lung cancer (LUME-Lung 1): a phase 3, double-blind, randomised controlled trial. Lancet Oncol 2014; 15: 143-155.

63 Rizvi NA, Riely GJ, Azzoli CG, et al. Phase I/II trial of weekly intravenous 130-nm albumin-bound paclitaxel as initial chemotherapy in patients with stage IV non-small-cell lung cancer. J Clin Oncol 2008; 26: 639-643.

64 Socinski MA, Bondarenko I, Karaseva NA, et al. Weekly nab-Paclitaxel in combination with carboplatin versus solvent-based paclitaxel plus carboplatin as first-line therapy in patients with advanced non-small-cell lung cancer: final results of a phase III trial. J Clin Oncol 2012; 30: 2055-2062.

65 Spratlin JL, Cohen RB, Eadens M, et al. Phase I pharmacologic and biologic study of ramucirumab (IMC-1121B), a fully human immunoglobulin G1 monoclonal antibody targeting the vascular endothelial growth factor receptor-2. J Clin Oncol 2010; 28: 780-787.

66 Garon EB, Ciuleanu T-E, Arrieta O, et al. Ramucirumab plus docetaxel versus placebo plus docetaxel for second-line treatment of stage IV non-small-cell lung cancer after disease progression on platinum-based therapy (REVEL): a multicentre, double-blind, randomised phase 3 trial. Lancet 2014; 384: 665-673.

67 Kuenen B, Witteveen PO, Ruijter R, et al. A phase I pharmacologic study of necitumumab (IMC-11F8), a fully human IgG1 monoclonal antibody directed against EGFR in patients with advanced solid malignancies. Clin Cancer Res 2010; 16: 1915-1923. 
68 Thatcher N, Hirsch FR, Luft AV, et al. Necitumumab plus gemcitabine and cisplatin versus gemcitabine and cisplatin alone as first-line therapy in patients with stage IV squamous non-small-cell lung cancer (SQUIRE): an open-label, randomised, controlled phase 3 trial. Lancet Oncol 2015; 16: 763-774.

69 Gadgeel SM, Stevenson JP, Langer CJ, et al. Pembrolizumab and platinum-based chemotherapy as first-line therapy for advanced non-small-cell lung cancer: Phase 1 cohorts from the KEYNOTE-021 study. Lung Cancer 2018; 125: 273-281.

70 Paz-Ares L, Luft A, Vicente D, et al. Pembrolizumab plus chemotherapy for squamous non-small-cell lung cancer. N Engl J Med 2018; 379: 2040-2051.

71 Gandhi L, Rodriguez-Abreu D, Gadgeel S, et al. Pembrolizumab plus chemotherapy in metastatic non-small-cell lung cancer. N Engl J Med 2018; 378: 2078-2092.

72 Horn L, Mansfield AS, Szczęsna A, et al. First-line atezolizumab plus chemotherapy in extensive-stage small-cell lung cancer. N Engl J Med 2018; 379: 2220-2229.

73 Liu SV, Camidge DR, Gettinger SN, et al. Long-term survival follow-up of atezolizumab in combination with platinum-based doublet chemotherapy in patients with advanced non-small-cell lung cancer. Eur J Cancer 2018; 101: 114-122.

74 West $\mathrm{H}$, McCleod M, Hussein M, et al. Atezolizumab in combination with carboplatin plus nab-Paclitaxel chemotherapy compared with chemotherapy alone as first-line treatment for metastatic non-squamous non-small-cell lung cancer (IMpower130): a multicentre, randomised, open-label, phase 3 trial. Lancet Oncol 2019; 20: 924-937.

75 Socinski MA, Jotte RM, Cappuzzo F, et al. Atezolizumab for first-line treatment of metastatic nonsquamous NSCLC. N Engl J Med 2018; 378: 2288-2301.

76 Lee S-H, Lee J-K, Ahn M-J, et al. Vandetanib in pretreated patients with advanced non-small cell lung cancer-harboring RET rearrangement: a phase II clinical trial. Ann Oncol 2017; 28: 292-297.

77 Paz-Ares L, Hirsh V, Zhang L, et al. Monotherapy Administration of Sorafenib in Patients With Non-Small Cell Lung Cancer (MISSION) Trial: a phase III, multicenter, placebo-controlled trial of sorafenib in patients with relapsed or refractory predominantly nonsquamous non-small-cell lung cancer after 2 or 3 previous treatment regimens. J Thorac Oncol 2015; 10: 1745-1753.

78 Baggstrom MQ, Socinski MA, Wang XF, et al. Maintenance sunitinib following initial platinum-based combination chemotherapy in advanced-stage IIIB/IV non-small cell lung cancer: a randomized, double-blind, placebo-controlled phase III study-CALGB 30607 (Alliance). J Thorac Oncol 2017; 12: 843-849.

79 Gatzemeier U, Heller A, Foernzler D, et al. Exploratory analyses EGFR, kRAS mutations and other molecular markers in tumors of NSCLC patients (pts) treated with chemotherapy $+/$ - erlotinib (TALENT). $J$ Clin Oncol 2005; 23: 7028-7028.

80 Herbst RS, Prager D, Hermann R, et al. TRIBUTE: a phase III trial of erlotinib hydrochloride (OSI-774) combined with carboplatin and paclitaxel chemotherapy in advanced non-small-cell lung cancer. J Clin Oncol 2005; 23: 5892-5899.

81 Kim ES, Hirsh V, Mok T, et al. Gefitinib versus docetaxel in previously treated non-small-cell lung cancer (INTEREST): a randomised phase III trial. Lancet 2008; 372: 1809-1818.

82 Thatcher N, Chang A, Parikh P, et al. Gefitinib plus best supportive care in previously treated patients with refractory advanced non-small-cell lung cancer: results from a randomised, placebo-controlled, multicentre study (Iressa Survival Evaluation in Lung Cancer). Lancet 2005; 366: 1527-1537.

83 Lynch TJ, Bell DW, Sordella R, et al. Activating mutations in the epidermal growth factor receptor underlying responsiveness of non-small-cell lung cancer to gefitinib. N Engl J Med 2004; 350: 2129-2139.

84 Kim ES, Hirsh V, Mok T, et al. Gefitinib versus docetaxel in previously treated non-small-cell lung cancer (INTEREST): a randomised phase III trial. Lancet 2008; 372: 1809-1818.

85 Ai X, Guo X, Wang J, et al. Targeted therapies for advanced non-small cell lung cancer. Oncotarget 2018; 9 : 37589-37607.

86 Farago AF, Taylor MS, Doebele RC, et al. Clinicopathologic features of non-small-cell lung cancer harboring an NTRK gene fusion. JCO Precis Oncol 2018; 2018: PO.18.00037.

87 Schiller JH, Harrington D, Belani CP, et al. Comparison of four chemotherapy regimens for advanced nonsmall-cell lung cancer. N Engl J Med 2002; 346: 92-98.

88 Yamamoto N, Mera T, Märten A, et al. Observational study of sequential afatinib and osimertinib in EGFR mutation-positive NSCLC: patients treated with a 40-mg starting dose of afatinib. Adv Ther 2020; 37: 759-769.

89 Shaw AT, Riely GJ, Bang Y-J, et al. Crizotinib in ROS1-rearranged advanced non-small-cell lung cancer (NSCLC): updated results, including overall survival, from PROFILE 1001. Ann Oncol 2019; 30: 1121-1126.

90 Planchard D, Kim TM, Mazieres J, et al. Dabrafenib in patients with BRAFV600E-positive advanced non-small-cell lung cancer: a single-arm, multicentre, open-label, phase 2 trial. Lancet Oncol 2016; 17: 642-650.

91 Prowell TM, Theoret MR, Pazdur R. Seamless oncology-drug development. N Engl J Med 2016; 374: 2001-2003. 
92 Kauffmann-Guerrero D, Tufman A, Kahnert K, et al. Response to checkpoint inhibition in non-small cell lung cancer with molecular driver alterations. Oncol Res Treat 2020; 43: 289-298.

93 Spigel DR, Edelman MJ, O'Byrne K, et al. Results From the Phase III randomized trial of onartuzumab plus erlotinib versus erlotinib in previously treated Stage IIIB or IV non-small-cell lung cancer: METLung. J Clin Oncol 2016; 35: 412-420.

94 Hirsch FR, Govindan R, Zvirbule Z, et al. Efficacy and safety results from a phase II, placebo-controlled study of onartuzumab plus first-line platinum-doublet chemotherapy for advanced squamous cell non-small-cell lung cancer. Clin Lung Cancer 2017; 18: 43-49.

95 Spigel DR, Ervin TJ, Ramlau RA, et al. Randomized phase II trial of onartuzumab in combination with erlotinib in patients with advanced non-small-cell lung cancer. J Clin Oncol 2013; 31: 4105-4114. 